\title{
Characterising aerosol transport into the Canadian High Arctic using aerosol mass spectrometry and Lagrangian modelling
}

\author{
T. Kuhn ${ }^{1}$, R. Damoah ${ }^{2}$, A. Bacak ${ }^{3}$, and J. J. Sloan ${ }^{2}$ \\ ${ }^{1}$ Department of Space Science, Luleå University of Technology, Kiruna, Sweden \\ ${ }^{2}$ Department of Earth and Environmental Sciences, University of Waterloo, Waterloo, ON N2L 3G1, Canada \\ ${ }^{3}$ School of Earth, Atmospheric and Environmental Sciences, The University of Manchester, Williamson Building, Oxford \\ Road, Manchester, M13 9PL, UK
}

Received: 1 April 2010 - Published in Atmos. Chem. Phys. Discuss.: 26 May 2010

Revised: 20 September 2010 - Accepted: 27 September 2010 - Published: 8 November 2010

\begin{abstract}
We report the analysis of measurements made using an aerosol mass spectrometer (AMS; Aerodyne Research Inc.) that was installed in the Polar Environment Atmospheric Research Laboratory (PEARL) in summer 2006. PEARL is located in the Canadian high Arctic at $610 \mathrm{~m}$ above sea level on Ellesmere Island $\left(80^{\circ} \mathrm{N} 86^{\circ} \mathrm{W}\right)$. PEARL is unique for its remote location in the Arctic and because most of the time it is situated within the free troposphere. It is, therefore, well suited as a receptor site to study the long-range tropospheric transport of pollutants into the Arctic. Some information about the successful year-round operation of an AMS at a high Arctic site such as PEARL will be reported here, together with design considerations for reliable sampling under harsh low-temperature conditions. Computational fluid dynamics calculations were made to ensure that sample integrity was maintained while sampling air at temperatures that average $-40^{\circ} \mathrm{C}$ in the winter and can be as low as $-55^{\circ} \mathrm{C}$. Selected AMS measurements of aerosol mass concentration, size and chemical composition recorded during the months of August, September and October 2006 will be reported. The air temperature was raised to about $20^{\circ} \mathrm{C}$ during sampling, but the short residence time in the inlet system $(\sim 25 \mathrm{~s})$ ensured that less than $10 \%$ of semivolatiles such as ammonium nitrate were lost. During this period, sulfate was, at most times, the predominant aerosol component with on average $0.115 \mu \mathrm{g} \mathrm{m} \mathrm{m}^{-3}$ (detection limit $0.003 \mu \mathrm{g} \mathrm{m}^{-3}$ ). The second most abundant component was undifferentiated organic aerosol, with on av-
\end{abstract}

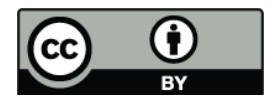

Correspondence to: J. J. Sloan (sloanj@uwaterloo.ca) erage $0.11 \mu \mathrm{g} \mathrm{m}^{-3}$ (detection limit $0.04 \mu \mathrm{g} \mathrm{m}^{-3}$ ). The nitrate component, which averaged $0.007 \mu \mathrm{g} \mathrm{m}^{-3}$, was above its detection limit $\left(0.002 \mu \mathrm{g} \mathrm{m}^{-3}\right)$, whereas the ammonium ion had an apparent average concentration of $0.02 \mu \mathrm{g} \mathrm{m}^{-3}$, which was approximately equal to its detection limit. A few episodes, having increased mass concentrations and lasting from several hours to several days, are apparent in the data. These were investigated further using a statistical analysis to determine their common characteristics. High correlations among some of the components arriving during the shortterm episodes provide evidence for common sources. Lagrangian methods were also used to identify the source regions for some of the episodes. In all cases, these coincided with the arrival of air that had contacted the surface at latitudes below about $60^{\circ} \mathrm{N}$. Most of these lower-latitude footprints were on land, but sulfate emissions from shipping in the Atlantic were also detected. The Lagrangian results demonstrate that there is direct transport of polluted air into the high Arctic (up to $80^{\circ} \mathrm{N}$ ) from latitudes down to $40^{\circ} \mathrm{N}$ on a time scale of 2-3 weeks. The polluted air originates in a wide variety of industrial, resource extraction and petroleumrelated activity as well as from large population centres.

\section{Introduction}

The Arctic is a relatively pristine environment, but it is not completely isolated from distant anthropogenic influences. Information about transport of pollution into the Arctic is documented regularly in the reports of the Arctic Monitoring and Assessment Programme (AMAP), which identify

Published by Copernicus Publications on behalf of the European Geosciences Union. 
the large-scale tropospheric pathways whereby pollutants are brought from low to high latitudes (AMAP, 2003). One of the most dramatic consequences of this pollution, Arctic haze, is associated with the intrusion of polluted air into the Arctic in winter and spring, when anthropogenic sources and the Arctic are within the same (cold) air masses (Heintzenberg, 1989). Related to this, early measurements showed that anthropogenic aerosols from low latitudes are an important component of Arctic contamination (Hoff et al., 1983). Possibly more important are semi-volatile organic pollutants like pesticides which, like the aerosols, have no high latitude sources, yet are found in high concentrations at many Arctic locations (e.g., Bailey et al., 2000; Halsall et al., 1998; Hung et al., 2005; Oehme, 1991; Oehme and Ottar, 1984). The presence of these clearly identifiable contaminants demonstrates the existence of transport pathways for anthropogenic pollutants into the Arctic.

Much work has been done during more than two decades to identify the sources of these materials. This effort is made more difficult by recent indications that the predominant locations of emission sources may be changing (Hung et al., 2005; Sirois and Barrie, 1999). Some reports suggest that these originate in regions of Eurasia, but parts of North America have also been indicated for some receptor locations (Halsall et al., 1997; Nyeki et al., 2005; Pacyna, 1995; Polissar et al., 2001; Xie et al., 1999). For these reasons and many others relating to the health of the affected communities, it is important to continue the efforts to monitor and understand long range transport of pollutants into the Arctic.

Particulate matter (PM) in the smaller size ranges (e.g., $\mathrm{PM}_{1}$ ), which is transported over long distances (Saarikoski et al., 2008; Sehili and Lammel, 2007), is a useful tracer for the origins of this material as well as a vector for transport of contaminants (Lammel et al., 2009). Many of the important effects occur at Arctic sunrise when photochemical processes begin after months of darkness. Aerosols also cause important radiative effects in the Arctic. For example, increases in the number and size of sulfate aerosols from photo-oxidation of $\mathrm{SO}_{2}$ can cause surface cooling by reflecting incoming radiation (Hung et al., 2005; Sirois and Barrie, 1999), whereas aerosols of other sizes and compositions can have warming effects. Thus, there is a strong connection between the chemical compositions of aerosols and their radiative effects.

There have been many studies of the chemical compositions of Arctic aerosols (e.g., Covert and Heintzenberg, 1993; Heidam et al., 1993; Heintzenberg and Leck, 1994; Sirois and Barrie, 1999; Staebler et al., 1999), some of which also report particle size information (Barrie et al., 1994; Hillamo et al., 2001; Ricard et al., 2002; Teinilä et al., 2003). Not all studies include organic matter, which is a significant fraction of the aerosol (Heintzenberg, 1989) and studies that do include organics usually focus only on toxics like pesticides (Hung et al., 2005) or selected compounds such as dicarboxylic acids (e.g., Narukawa et al., 2002; Teinilä et al., 2003), thereby omitting most of the organic mass fraction.
Finally, most Arctic measurement sites represented in the data referenced above are at or close to sea level, which is a disadvantage when studying long range transport occurring in the free troposphere. Exceptions to this include the Zeppelin site close to Ny-Ålesund on Svalbard, which at $474 \mathrm{~m}$ a.s.l., is located in the free troposphere for much of the time. This site has been used for measurements of aerosol chemical composition in several studies (Heintzenberg and Leck, 1994; Ström et al., 2003; Teinilä et al., 2004). Clearly, it is desirable to have more measurements of aerosol size and composition in the high Arctic. Additionally, the temporal variation of these parameters is less well characterised than the average values and this is also an extremely important factor to explore.

In the following, we report selected measurements of the temporal variations in aerosol size and composition that were carried out at the Polar Environment Atmospheric Research Laboratory (PEARL) in the Canadian Arctic. Located at $80^{\circ} 02^{\prime} \mathrm{N}, 86^{\circ} 15^{\prime} \mathrm{W}$ at an elevation of $610 \mathrm{~m}$, PEARL is in the free troposphere and, thus, is ideally suited for studying aerosol transport into the Arctic. The measurements were done using an aerosol mass spectrometer (AMS; Aerodyne Research Inc.) that provides a continuous data record with high temporal resolution. These measurements are the first recorded by an AMS in the Arctic and, to the knowledge of the authors, they represent the first time that ground-based, real-time chemical analysis of Arctic aerosols has been attempted. We describe here the sampling site and some design features of the installation that were necessitated by the need to ensure the integrity of the samples under the harsh conditions of the PEARL laboratory. Computational fluid dynamics (CFD) simulations of the inlet system are reported, to verify that particles in the size range that can be detected by the instrument were sampled efficiently. We also report analyses by several methods of episodes relevant for studies of long range transport. Statistical analyses and Lagrangian modelling of these were used to provide information about common sources and geographical locations.

\section{Site and installation details}

\subsection{Polar Environment Atmospheric Research Laboratory (PEARL)}

The PEARL laboratory is a facility of the Canadian Network for the Detection of Atmospheric Change (CANDAC) in the Canadian high Arctic. It is located on Ellesmere Island in Nunavut, Canada, $9 \mathrm{~km}$ west from Eureka $\left(79^{\circ} 59^{\prime} \mathrm{N}\right.$, $85^{\circ} 56^{\prime} \mathrm{W}$ ), which is a Canadian High Arctic Weather Station (HAWS). About two kilometres east of the weather station is the Eureka airport and a small military base. Eureka is $160 \mathrm{~km}$ north of the nearest community (Grise Fjord) and about $150 \mathrm{~km}$ south-west of the Canadian Forces Station (CFS) Alert, which is home to a more substantial military 
presence, as well as another HAWS. The PEARL laboratory is located on top of a $610 \mathrm{~m}$ ridge, a few kilometres east of Eureka Sound, which runs North-South, and just north of Slidre Fjord, which runs East-West. The neighbouring hills are at similar or lower altitudes, so the laboratory is located within the free troposphere almost all of the time. These geographical features make PEARL an ideal and unique site for an Arctic observatory.

Between 1993 and 2002, the facility, then called the Arctic Stratospheric Observatory (AStrO), was used by Environment Canada (EC) for (mostly) stratospheric observations. The Arctic atmospheric research program at PEARL was initiated under new funding from the Canadian Foundation for Climate and Atmospheric Sciences (CFCAS), the Canada Foundation for Innovation (CFI), the Ontario Innovation Trust (OIT) and the Atlantic Innovation Fund (AIF)/Nova Scotia Research and Innovation Trust (NSRIT). Several new CANDAC programmes made possible by this funding have expanded the research scope into the lower atmosphere. Since summer 2005, PEARL has been operated year-round by CANDAC. One to three operators maintain the facility and oversee the experiments. Electric power for the laboratory in Eureka is produced by a diesel generating plant, which is located away from the prevailing wind direction, so measurements at PEARL are not affected by local pollution sources, another important asset of the laboratory.

\subsection{AMS installation}

An AMS from Aerodyne Research Inc. (Canagaratna et al., 2007; Jayne et al., 2000; Jimenez et al., 2003) was installed at PEARL in August 2006. The AMS provides near real-time size resolved composition analysis of non-refractory particulate matter in the size range from approximately $80 \mathrm{~nm}$ to $700 \mathrm{~nm}$ vacuum aerodynamic diameter (Liu et al., 2007). During operation, particles are aerodynamically focused in a high-vacuum system (Liu et al., 2007) onto a heated surface (temperature $\sim 540^{\circ} \mathrm{C}$ ) where non-refractory components are thermally vapourised and analysed by electron impact $(70 \mathrm{eV})$ ionization quadrupole mass spectrometry. The instrument at PEARL (a 215 series AMS) has a particle timeof-flight (TOF) path of $293 \mathrm{~mm}$ and a critical orifice diameter of $0.1 \mathrm{~mm}$, which fixes the inlet flow rate at approximately $1.3 \mathrm{~cm}^{3} \mathrm{~s}^{-1}\left(\approx 80 \mathrm{ml} \mathrm{min}^{-1}\right)$.

The AMS is operated at normal room temperature of approximately $20^{\circ} \mathrm{C}$ inside the PEARL laboratory. An air stream of $11 \mathrm{~L} \mathrm{~min}^{-1}$ (laboratory temperature and pressure) is sampled through an inlet assembly located about $2.2 \mathrm{~m}$ above the roof of the laboratory and flows to the AMS through a $22 \mathrm{~mm}$ inner diameter (ID) stainless steel inlet pipe, which is approximately $7.2 \mathrm{~m}$ long. The flow rate and pipe dimension results in laminar flow with a Reynolds number $(\mathrm{Re})$ of approximately 700 . Close to the AMS, the flow is split in three parts: a $1 \mathrm{~L} \mathrm{~min}^{-1}$ flow to the AMS and two $5 \mathrm{~L} \mathrm{~min}^{-1}$ flows, which can be used to sample total sus-

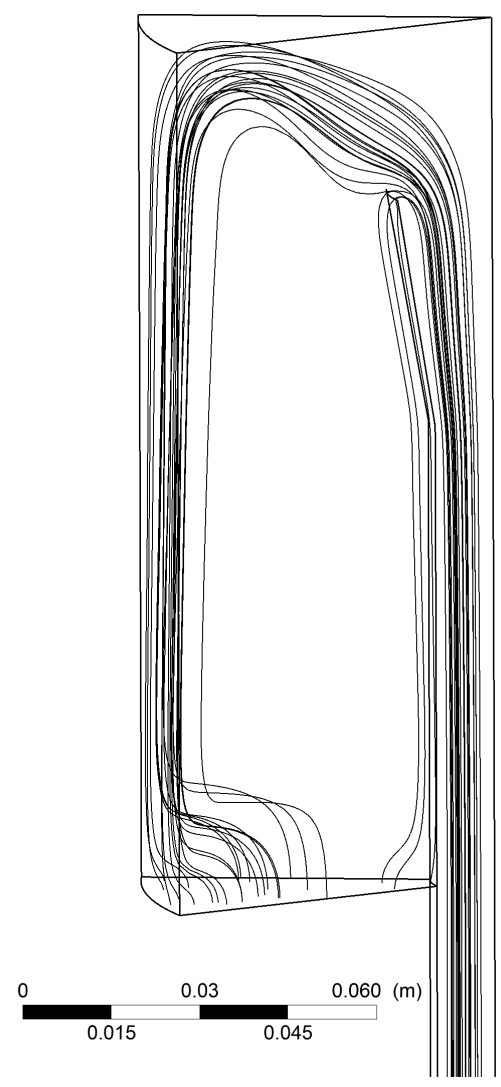

Fig. 1. A $30^{\circ}$ radial section is used to model the flow through the inlet assembly with CFD. Air at $-40^{\circ} \mathrm{C}$ and $1 \mu \mathrm{m}$ diameter particles (density of $1000 \mathrm{~kg} \mathrm{~m}^{-3}$ ) are introduced through the opening at the bottom of the inlet. The outer surface and the inlet pipe in the centre (ending in a funnel at the top) are heated to $20^{\circ} \mathrm{C}$. Trajectories of the $1 \mu \mathrm{m}$ particles are depicted as grey lines.

pended particles (TSP) and $\mathrm{PM}_{1}$ on filters. (The latter measurements will not be reported here.) The $1 \mathrm{~L} \mathrm{~min}^{-1}$ flow is transferred to the inlet of the AMS through a $37 \mathrm{~cm}$ long, $5.2 \mathrm{~mm}$ ID stainless steel tube at $R e \approx 300$. A stainless steel tube approximately $15.5 \mathrm{~cm}$ long and $2 \mathrm{~mm}$ ID sub-samples the AMS inlet flow rate of $80 \mathrm{ml} \mathrm{min}^{-1}$ from the core of the $1 \mathrm{~L} \mathrm{~min}^{-1}$ flow and delivers it to the critical orifice of the AMS inlet. This sub-sampling is slightly sub-isokinetic; the mean speed in the $2 \mathrm{~mm}$ ID sampling tube is approximately half of the mean speed in the $5.2 \mathrm{~mm}$ ID tube with the $1 \mathrm{~L} \mathrm{~min}^{-1}$ flow. This, however, does not present a problem, because the inertia of $1 \mu \mathrm{m}$ particles is negligible (Stokes' number $S t k=0.001$ for $1 \mu \mathrm{m}$ particle with density of water and $2 \mathrm{~mm}$ ID sampling tube). Thus, the sub-sample of $1 \mu \mathrm{m}$ and smaller particles is representative of the sample in the $1 \mathrm{~L} \mathrm{~min}^{-1}$ flow.

Figure 1 shows a $30^{\circ}$ radial section through the inlet assembly on the laboratory roof. The outer surface is an inverted, heated cylindrical cup (120 mm ID), which is insulated on the outside. The cup surrounds the inlet pipe, which 
is flared slightly at the top to resemble a funnel, with a $38.1 \mathrm{~mm}$ diameter top opening that narrows to $25.4 \mathrm{~mm}$ at the bottom. Both the funnel and the cover are maintained at a temperature of $20^{\circ} \mathrm{C}$ in order to bring the sampled air to room temperature quickly when it enters the inlet. This removes larger ice crystals that might otherwise not evaporate completely before being sampled by the AMS (Staebler et al., 1999). After passing through the inlet assembly, air enters the inlet pipe, which passes through a $10 \mathrm{~cm}$ diameter, $3 \mathrm{~m}$ long PVC tube mounted in an insulated hatch in the roof of the room where the AMS is located.

Care was taken to ensure that the sampling system would work properly, even for the lowest $\left(-55^{\circ}\right)$ outside temperatures encountered in the winter. The temperature changes caused by bringing the sampled air to the temperature of the AMS inlet could cause buoyancy effects, which might give rise to convective recirculation of the sampled air stream inside the inlet pipe. For simple flow geometries it is sufficient to estimate the effects of buoyancy using the buoyancy parameter, $\mathrm{Gr} / \mathrm{Re}^{2}$ (Incropera and DeWitt, 1999), which is a dimensionless number that compares the strength of buoyant forces with that of inertial forces using a characteristic length (the tube diameter) and temperature difference (here the difference between wall and gas temperatures). When $\mathrm{Gr} / \mathrm{Re}^{2}$ is smaller than unity, the flow is dominated by inertial forces and buoyancy can be neglected. In case of the main inlet pipe, in which the flow is $11 \mathrm{~L} \mathrm{~min}^{-1}$, even a temperature difference of $60^{\circ} \mathrm{C}$ between the tube wall and the gas would only result in a buoyancy parameter of 0.2 . For typical temperature differences of about $10^{\circ} \mathrm{C}$, the buoyancy parameter would be 0.03 , so buoyancy inside the main inlet pipe is not important and we can safely neglect it.

The inlet assembly leading to the funnel at the top of the inlet pipe is designed to raise the temperature of the sample from that of the (possibly very cold) ambient outside air to that of the AMS. Since the flow speeds are slowest in this region, the inertial forces are weakest and it is not possible to exclude convective recirculation simply on the basis of the buoyancy parameter, which in this case is larger than unity. Therefore, we have modelled the flow in the inlet assembly using computational fluid dynamics (CFD) (ANSYS CFX; ANSYS 11.0, ANSYS Inc. Canonsburg, PA, USA).

Figure 1 shows the CFD-calculated trajectories of $1 \mu \mathrm{m}$ diameter particles (density of $1000 \mathrm{~kg} \mathrm{~m}^{-3}$ ) that were released across the cross-section of the opening at the bottom of the inlet. For this purpose, the air entering the opening was assumed to have a temperature of $-40^{\circ} \mathrm{C}$. The CFD analysis shows that buoyant forces cause the air and particles to rise faster in the proximity of the heated walls than in the other parts of the inlet. This draws the particles closer to the heated wall, enhancing the heat transfer to them and directing them to the region above the inlet pipe, from which they are swept into the top of the funnel. The air in the central region of the gap between the inlet pipe and the heated can is nearly stagnant. The slow circulation there does not affect particles in the size range detectable by the AMS (approximately $80 \mathrm{~nm}$ to $700 \mathrm{~nm}$ ). Particles larger than about $25 \mu \mathrm{m}$ (aerodynamic diameter) are eliminated in the inlet by elutriation (they are too heavy and are not carried up into the inlet), while particles with diameters of $10 \mu \mathrm{m}$ or smaller have transmission efficiency through the inlet region of $100 \%$.

The CFD results also verified the effective heating of air in the inlet. The air inside the funnel reaches a temperature $\geq 15^{\circ} \mathrm{C}$ when the sampled air is at $-40^{\circ} \mathrm{C}$ if the inlet wall is kept at $20^{\circ} \mathrm{C}$. The particles are heated to the same temperature as the air, because heating of particles by collisions with air molecules is fast compared to transport times through the inlet.

After entering the inlet pipe, the air flows through three $90^{\circ}$ bends before being sampled by the AMS: the first is a Swagelok Tee where $6 \mathrm{~L} \mathrm{~min}^{-1}$ is taken from the $11 \mathrm{~L} \mathrm{~min}^{-1}$ inlet flow; the second is a $90^{\circ}$ elbow; and the third is another Tee, where $1 \mathrm{~L} \mathrm{~min}^{-1}$ is split from the $6 \mathrm{~L} \mathrm{~min}^{-1}$ flow. At a flow rate of $6 \mathrm{~L} \mathrm{~min}^{-1}$, losses at a $90^{\circ}$ bend in a tube with ID of $22 \mathrm{~mm}$ (approximating the first Swagelok Tee) are very close to zero. For particles of $10 \mu \mathrm{m}$ aerodynamic diameter, the transport efficiency through the bend is $99 \%$ (Hinds, 1999). This may also be confirmed directly from the fact that the Stokes numbers in this flow for particles having diameters less than $10 \mu \mathrm{m}$ are much smaller than unity (approximately $6 \times 10^{-3}$ and $7 \times 10^{-5}$ for $10 \mu \mathrm{m}$ and $1 \mu \mathrm{m}$ particles, respectively). Hence, particles smaller than $1 \mu \mathrm{m}$, which is above the upper limit for detection by the AMS, will follow the air stream without problems. Similar calculations confirm that losses in the other two bends for particles smaller than $10 \mu \mathrm{m}$ are also close to zero, a result that was also confirmed using CFD modelling of particle flow through these bends.

Diffusion losses in the sampling line were also evaluated using (Gormley and Kennedy, 1949). The $11 \mathrm{~L} \mathrm{~min}^{-1}$ flow through the $7.2 \mathrm{~m}$ long sampling pipe yields a transmission efficiency of $99.3 \%$ for $70 \mathrm{~nm}$ particles (below lower detection limit of AMS, which detects particles of about $80 \mathrm{~nm}$ with a $50 \%$ efficiency, Liu et al., 2007). Transmission efficiencies in the sections having $6 \mathrm{~L} \mathrm{~min}^{-1}$ and $1 \mathrm{~L} \mathrm{~min}^{-1}$ flows are even higher. The $15.5 \mathrm{~cm}$ long tube through which the AMS samples with its $80 \mathrm{ml} \mathrm{min}^{-1}$ flow has the lowest transmission efficiency with $98.6 \%$ for $80 \mathrm{~nm}$ particles. Overall, the diffusion losses should amount to about $3 \%$ for particles with $70 \mathrm{~nm}$ diameter and losses for larger particles are smaller.

The mean residence time of air in our inlet system is approximately $25 \mathrm{~s}$ (determined by the flow speed in the sampling tubes). This relatively low residence time is achieved by choosing a high flow rate in the $7.2 \mathrm{~m}$ straight sampling pipe. It assures that sampling losses due to evaporation of the more volatile aerosol components remain small. For example, direct measurements (Bergin et al., 1997) show that there would be less than $10 \%$ loss of pure ammonium nitrate aerosol in $25 \mathrm{~s}$ at $20^{\circ} \mathrm{C}$. This is an upper limit for the loss in 


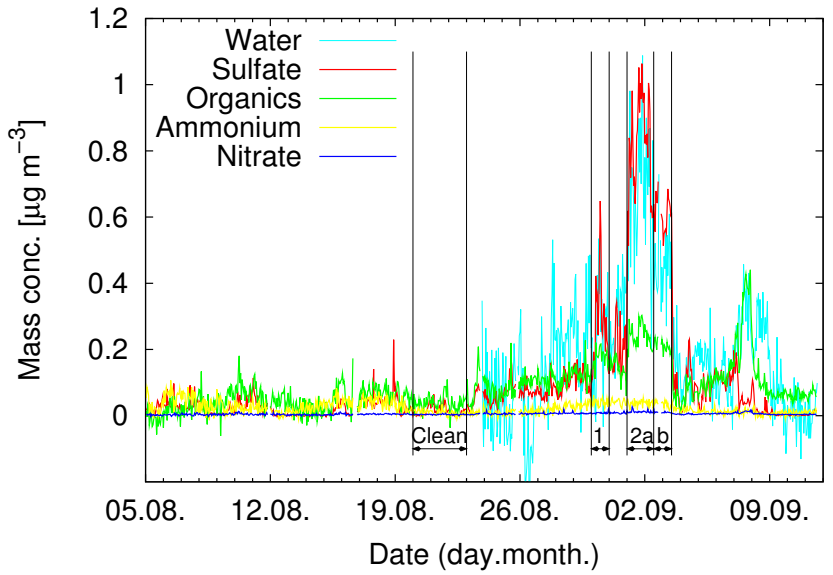

Fig. 2. Time series of AMS mass concentrations of sulfate, total organics, ammonium and nitrate for the aerosol sampled between 5 August 2006 and 11 September 2006. Four periods were selected for subsequent analysis. These are labelled "Clean" (indicating low levels of all detected species) and 1, 2a and 2b, during which high sulfate levels were detected. See Figs. 9-12 for Lagrangian modelling of these periods.

our measurement, since evaporation will be even slower for internally mixed aerosol (Stelson and Seinfeld, 2007).

\subsection{Sampling protocol}

For the results reported here, the AMS operated continuously using a one-hour signal averaging cycle. The averaged aerosol mass spectrum, acquired in the MS mode (Jimenez et al., 2003), and size distributions of selected species, acquired in the TOF mode (Jimenez et al., 2003) are saved each hour and then analysed using previously-developed methods (Alfarra et al., 2004; Allan et al., 2003a, b; Allan et al., 2004; Jimenez et al., 2003). Calibration procedures are carried out once per week, including the adjustment of the electron multiplier voltage and determination of its gain. Calibration of the overall ionization and detection efficiency (IE) (Allan et al., 2003b; Canagaratna et al., 2007; Jimenez et al., 2003) is performed using a narrow size range selected from a polydisperse ammonium nitrate aerosol (Jayne et al., 2000). Our procedure differs slightly from the conventional AMS calibration (Allan et al., 2003b; Canagaratna et al., 2007; Jimenez et al., 2003), which generates the monodisperse test aerosol using a differential mobility analyser. We use a polydisperse aerosol together with the sizing capability of the AMS, which is calibrated using size certified polystyrene latex spheres (Jayne et al., 2000). Tests performed in the laboratory prior to installation at PEARL showed that our method gave 10 to $15 \%$ lower IE values.

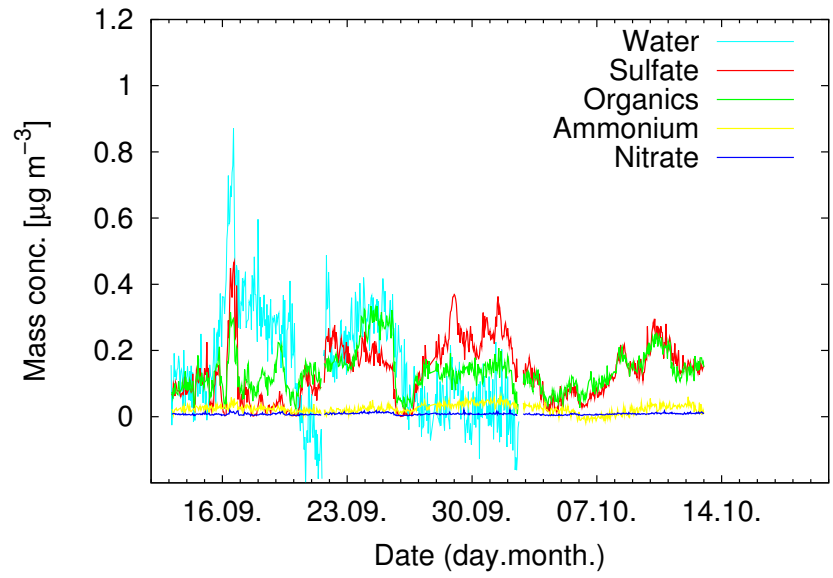

Fig. 3. Time series of AMS mass concentrations of sulfate, total organics, ammonium and nitrate for the aerosol sampled between 13 September 2006, 00:00 UTC and 13 October 2006, 00:00 UTC.

\section{Results}

The mass concentrations of the chemical species were determined from the measured mass spectra using the fragmentation table as described by (Allan et al., 2004). The lower detection limits for these mass concentrations were estimated as three times the standard deviation of the hourly averages during periods with close to zero concentrations (Allan et al., 2003a; Rupakheti et al., 2005). For a period with relatively low and constant concentrations (10 to 11 September 2006), this yielded detection limits of $0.02 \mu \mathrm{g} \mathrm{m}^{-3}$ for ammonium, $0.002 \mu \mathrm{g} \mathrm{m}^{-3}$ for nitrate, $0.003 \mu \mathrm{g} \mathrm{m}^{-3}$ for sulfate and $0.04 \mu \mathrm{g} \mathrm{m}^{-3}$ for organics.

Figures 2 and 3 show time series of AMS mass concentrations of sulfate, total organics, ammonium and nitrate for the aerosol sampled between 5 August 2006 and 12 October 2006, a period with high data coverage (valid data were collected during $97 \%$ of the time). The water mass concentration is shown only for particle-bound water (i.e., when water obviously correlates with one of the particulate signals). Thus, water signals due to varying air humidity levels are ignored (see below). For this period the average mass concentrations for ammonium, nitrate, sulfate and organics were $0.02 \mu \mathrm{g} \mathrm{m}^{-3}, 0.007 \mu \mathrm{g} \mathrm{m}^{-3}, 0.115 \mu \mathrm{g} \mathrm{m}^{-3}$ and $0.11 \mu \mathrm{g} \mathrm{m}^{-3}$, respectively. Sulfate was present at concentrations significantly above our previously-defined detection limit. Sulfate occasionally appeared in strong, short-term episodes, three of which are labelled in Fig. 2 as 1, 2a and 2b. These will be further analysed in a later section. The organics and nitrate concentration were clearly above their detection limit most of the time, while most ammonium measurements were approximately at the detection limit. Therefore, the ammonium measurement was determined to be too noisy and was not considered in subsequent analyses. 


\subsection{Regional atmospheric chemistry}

The data recorded during the first months following the AMS installation give information about the local concentrations that is relevant for the interpretation of the episodes that we will describe later in this paper. During the sampling period, it was found that the absolute mass concentrations of ammonium and nitrate were very low (maxima $\sim 0.03-$ $0.05 \mu \mathrm{g} \mathrm{m}^{-3}$ ), whereas those of the organic and sulfate components were much higher (maxima $\sim 0.5$ and $1 \mu \mathrm{g} \mathrm{m}{ }^{-3}$, respectively). Ammonium nitrate will only form after all the sulfate has been neutralized, so the high sulfate/ammonium ratios indicate that very little ammonium nitrate was present during the sampling period. There is, however, a good correlation between nitrates and organics that persists through the whole dataset. This suggests strongly that the majority of the small nitrate mass concentrations that were observed stem from organic nitrates. This will be discussed further in the next Sect. 3.2. In this context, we note that if inorganic nitrate in the form of ammonium nitrate were present, it is possible that it might be partially re-partitioned from the aerosol to the gas phase during transit through the room temperature inlet following sampling from cold ambient conditions. If this occurred, however, the inorganic component would only be underestimated by less than $10 \%$, (see Sect. 2.2). In view of the discussion at the beginning of this section, however, it is clear that ammonium nitrate aerosol is negligible during the sampling period. Inorganic nitrate may be present in other forms than ammonium nitrate. Teinilä et al. (2004) found that during their measurements on Svalbard, the nitrate salts were most likely $\mathrm{NaNO}_{3}$ and $\mathrm{Ca}\left(\mathrm{NO}_{3}\right)_{2}$, which are non-volatile. They also show additional evidence that nitrate evaporation losses were minimal during their measurements.

Sirois and Barrie (1999) report 15 years weekly average measurements of aerosol composition at Alert, $150 \mathrm{~km}$ northeast of PEARL. Sulfate was the dominant aerosol component with average concentrations of around $1 \mu \mathrm{g} \mathrm{m}^{-3}$ in winter and a maximum of $2 \mu \mathrm{g} \mathrm{m}^{-3}$ in spring. This drops to a minimum of just below $0.1 \mu \mathrm{g} \mathrm{m}^{-3}$ in July and August, then starts to increase again and reaches about $0.2 \mu \mathrm{g} \mathrm{m}^{-3}$ in October. Hence, our average sulfate concentrations are very similar to the August-October values of this nearby station. Both nitrate and ammonium concentrations at Alert were roughly one tenth or less of the sulfate measurements and featured a similar seasonal trend, which was somewhat less pronounced than the sulfate one. Both species have minimum average concentrations in September of around $0.02 \mu \mathrm{g} \mathrm{m}^{-3}$. This is similar to our average ammonium results and somewhat higher than our nitrate measurements. Other major components at Alert were the refractory species $\mathrm{Na}, \mathrm{Cl}, \mathrm{Al}, \mathrm{Ca}$ and $\mathrm{Mg}$ (with concentrations similar to ammonium and nitrate); these cannot be measured with the AMS.

Sirois and Barrie (1999) could distinguish two sulfate components, neutralized ammonium sulfate and acidic sulfate, of which the latter was dominant after polar sunrise, presumably due to increased photo-oxidation of $\mathrm{SO}_{2}$. This is also consistent with our findings of acidic sulfate (see next Sect. 3.2), with the episodes of very acidic sulfate corresponding to periods of increased $\mathrm{SO}_{2}$ transport to our site (as we show with Lagrangian analysis, see Sect. 4).

Measurements from Greenland are reported by Heidam et al. (1993). The semi-weekly average concentrations from four years have seasonal trends similar to those observed at Alert. Sulfate was also in Greenland the predominant component with average concentrations between 0.1 and $0.3 \mu \mathrm{g} \mathrm{m}^{-3}$ during the August-October period, quite similar to our measurements.

\subsection{Correlations}

Correlations among the sulfate, organics and nitrate concentrations for the period shown in Figs. 2 and 3 give information about possible common origins for some of these species. The overall correlation coefficient between sulfate and organics for this period is $R^{2}=0.38$. A closer examination of the scatter plot shown in Fig. 4 for these two species, however, suggests that aerosols from at least two different sources were sampled. During an episode of high sulfate concentrations that lasted two and a half days $(61 \mathrm{~h}$, between 1 September 2006, 01:00 UTC and 3 September 2006, 13:00 UTC; shown in blue in Fig. 4), the measurements show a high correlation between sulfate and organics $\left(R^{2}=0.64\right)$, combined with a slowly-varying organic background of around $0.1 \mu \mathrm{g} \mathrm{m}^{-3}$ (i.e. the positive intercept in Fig. 4). Another subset of measurements with even higher sulfate-to-organics correlation occurred in the data sampled on ten consecutive days between 2 October 2006 and 12 October 2006. These data are shown in green in Fig. 4. In this case, the correlation coefficient is $R^{2}=0.80$, but there is no significant intercept, suggesting that both particulate organics and sulfate (possibly as precursor gases) arrive from the same source region in a background-free air mass. We will report the results of Lagrangian studies of these two episodes later in this paper. For the other time periods, the correlation coefficients are much lower (e.g., $R^{2}=0.06$ for 3 September 2006 to 11 September 2006). Although there are episodes of both high organic and sulfate particle concentrations during this period, the lack of correlation indicates that they come from different sources and/or geographic regions.

The overall sulfate-nitrate correlation during the same period (5 August 2006 to 12 October 2006) is also weak, with $R^{2}=0.24$, but the scatter plot shown in Fig. 5, reveals periods of higher correlation having similar structures to that of the sulfate-organics episode. These correspond roughly to the two groups of data with higher correlations shown in Fig. 4. The first group, which has sulfate $\left(\mathrm{SO}_{4}^{=}\right)$concentrations above $0.5 \mathrm{\mu g} \mathrm{m}^{-3}$ (episode between 1 September 2006, 01:00 UTC and 3 September 2006, 13:00 UTC), shows a different trend than points with $\mathrm{SO}_{4}^{=}$below about $0.4 \mu \mathrm{g} \mathrm{m}{ }^{-3}$. The second group, between 2 October 2006 and 12 October 


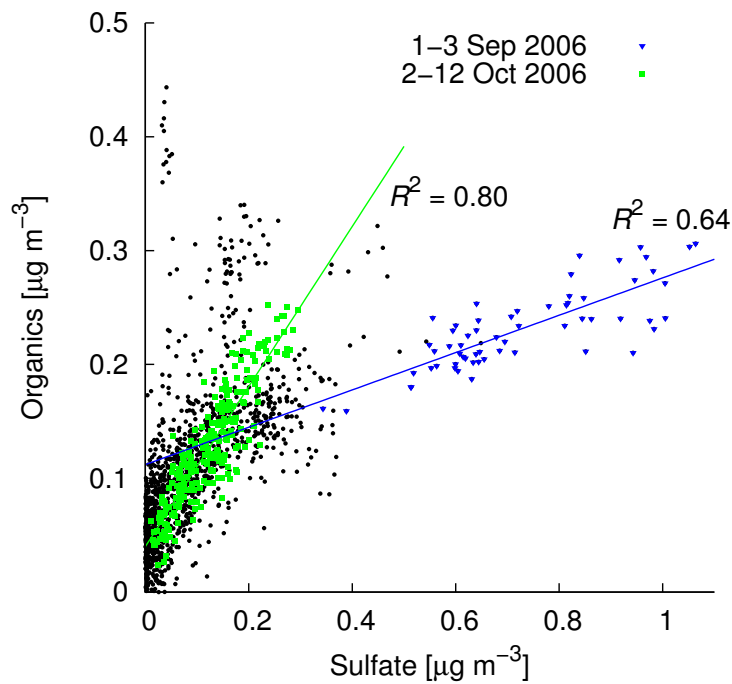

Fig. 4. Scatter plot of organics and sulfate concentrations showing data between 5 August 2006 and 12 October 2006. Two groups with exceptionally high correlations are indicated with blue and green points. The remaining data are shown as black points.

2006 (shown in green on the scatter plot in Fig. 5 and having $\mathrm{SO}_{4}^{=}$concentrations below $0.4 \mu \mathrm{g} \mathrm{m}^{-3}$ ) have a higher correlation coefficient, $R^{2}=0.50$, than during other periods.

The correlation between nitrate and organics, which is shown in Fig. 6, has a higher overall $R^{2}$ value of 0.45 . This correlation is consistent throughout the entire two months period studied, and no shorter episodes with significantly higher or lower correlation could be identified. This rough correlation between the nitrates and organics in the air at PEARL combined with the absence of natural sources for nitrates near the PEARL laboratory, suggests that both stem from air that is transported to PEARL from low latitude sources where nitrates are prevalent. Since there are no identifiable episodes of very high nitrate concentrations that would indicate localised sources, it is likely that the sources are geographically widespread. This is consistent with agricultural activity as the most likely source, as is the time period, which corresponds to the fall application of nitrate fertilizer. We will comment further on this in the section that reports the Lagrangian calculations.

Relatively low ratios of $\mathrm{NO}_{2}^{+}: \mathrm{NO}^{+}$(the two major nitrate fragments at $m / z=46$ and $m / z=30$; this ratio was 0.37 on average) are a further indication that organic nitrate aerosol accounts for most of the measured nitrate (Fry et al., 2009). During calibration of the AMS with ammonium nitrate this ratio is around 1 . These organic nitrates are most likely formed during transport and are responsible for the observed good correlation between nitrate and organics. This would also explain the different sulfate-nitrate trend that we pointed out above for data with sulfate concentrations higher than $0.5 \mu \mathrm{g} \mathrm{m}^{-3}$. These data were measured during an exception-

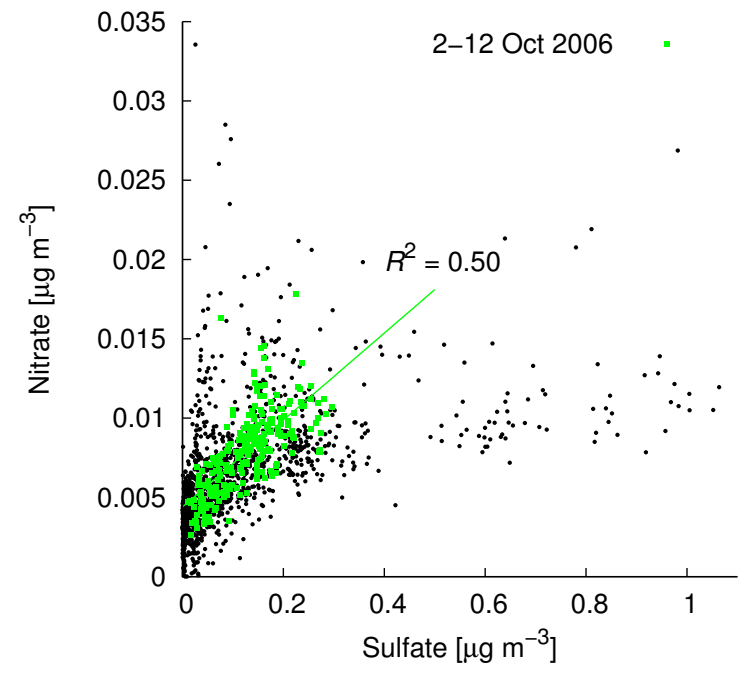

Fig. 5. Scatter plot of nitrate and sulfate concentrations showing data between 5 August 2006 and 12 October 2006. The overall correlation is weak with $R^{2}$ of 0.24 . One group with high correlation is indicated with green points. The remaining data are shown as black points.

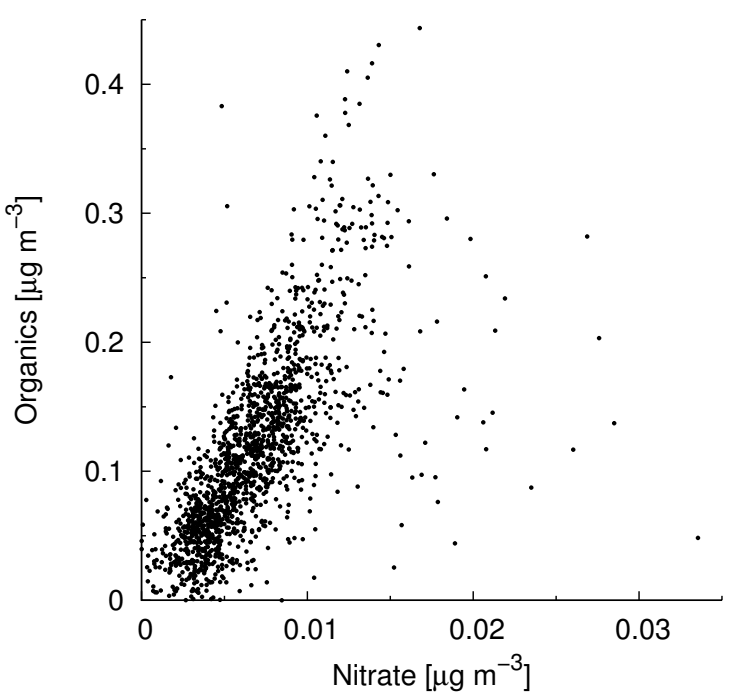

Fig. 6. Scatter plot of organics and nitrate concentrations showing data between 5 August 2006 and 12 October 2006. The consistent overall correlation has an $R^{2}$ value of 0.45 .

ally high sulfate episode around 2 September 2006 that was accompanied by a modest increase in the concentration of organics (see Fig. 2). The organic aerosol, however, remained correlated to nitrate during the entire episode.

Bae et al. (2007) suggested determining inorganic nitrate from $m / z=46$ only by using the $46 / 30$ ratio from calibration and assigning the remaining fraction of $m / z=30$ to organics. When applying this to our data, the inorganic nitrate as well as the organic part of the AMS nitrate measurement are both still correlated to organics $\left(R^{2} \approx 0.6\right)$. Therefore, 


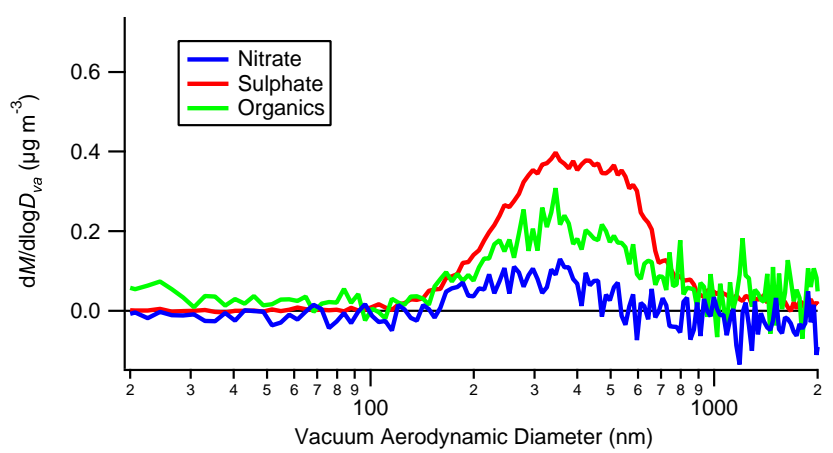

Fig. 7. Mass size distributions averaged over the period from 21 September 2006 to 2 October 2006 having above average sulfate and organics mass concentrations.

our discussions about nitrate are still valid even if we consider this inorganic nitrate only. The average concentration of inorganic nitrate is $0.03 \mu \mathrm{g} \mathrm{m}^{-3}$ (total nitrate from both fragments $m / z=30$ and 46 is $0.07 \mu \mathrm{g} \mathrm{m}^{-3}$ ).

While it is possible that sulfur might have been present in the form of ammonium sulfate or bisulfate during periods of low sulfate concentrations, the very low ammonium levels are inconsistent with these compounds being present during episodes with higher sulfur concentrations. This differs from typical urban environments, where most of the sulfur is present as ammonium sulfate and during shorter episodes of increased acidity, ammonium bisulfate is present as well (e.g., Zhang et al., 2005). This suggests that the sulfate aerosol detected during these episodes is probably very highly oxidized and is thus predominantly in the form of sulfuric acid.

\subsection{Size distributions}

Mass size distributions of the major chemical species are derived from the AMS measurements in TOF mode (Jimenez et al., 2003). The TOF size distributions shown in Fig. 7 are averaged over 21 September 2006 to 2 October 2006, a period that had above-average sulfate and organics mass concentrations. The size distributions have been normalized to the mass concentrations determined from measurements in the MS mode (Allan et al., 2003a, b). The sulfate has a distribution between (vacuum aerodynamic) diameters of approximately 200 and $700 \mathrm{~nm}$. The large diameter cutoff may be due in part to the reduced transmission efficiency of the AMS inlet system above this size (Jayne et al., 2000), because Liu et al. (2007) have shown that the transmission efficiency for particles of various compositions drops to about $50 \%$ at around $700 \mathrm{~nm}$. The sulfate distribution is very broad and the shape suggests that it might consist of two modes, one with maximum at approximately $300 \mathrm{~nm}$ and one at about $500 \mathrm{~nm}$ (or larger). The maximum in the organic aerosol size distribution is at about $350 \mathrm{~nm}$. A weak nitrate mode, similar in

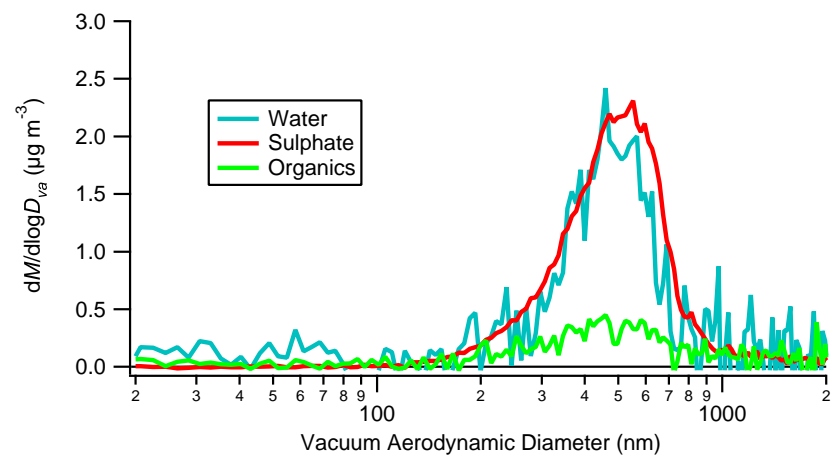

Fig. 8. Mass size distributions for an episode with exceptionally high sulfate concentrations (1 September 2006, 00:00 UTC to 2 September 2006, 19:00 UTC). During this episode particle-bound water was detected with a size distribution similar to the sulfate size distribution.

shape to the organics, is also evident in this size range. Both contributions from $m / z=30$ and 46 were considered for this nitrate mode. If only inorganic nitrate (proportional to the $m / z=46$ fragment) were used, then the TOF data would become too noisy to make any firm statement about the inorganic nitrate mode's location or shape.

Figure 8 shows the size distribution for the short period with exceptionally high sulfate concentration between 1 September 2006, 01:00 UTC and 2 September 2006, 19:00 UTC (average sulfate concentration of $0.79 \mu \mathrm{g} \mathrm{m}^{-3}$ ). The sulfate mode has a maximum at approximately $500 \mathrm{~nm}$; the maximum in the organic mode is at $450 \mathrm{~nm}$. No significant nitrate was observed during this period. There is, however, a high concentration of particle-bound water (i.e. water that was not evaporated from the particle before detection by the AMS). This can be seen in both the time series of total mass concentration and the TOF size distributions. Water that is evaporated from cloud or fog particles in the inlet is seen as fluctuations that have no correlation with the other components. In this case, however, the water signal showed a relatively high correlation with the sulfate $\left(R^{2}=0.46\right.$ in MS mode), whereas this $R^{2}$ value was 0.07 on the two days prior to this episode. Moreover, the water and sulfate have nearly identical mass size distributions as shown in Fig. 8, strongly suggesting that the water was contained in the sulfate particles and was not removed when these particles were heated to room temperature.

During all other periods no identifiable TOF water mode can be distinguished, even on those occasions when the mass concentration of water correlates with sulfate or organics. The absence of a water TOF mode means that little or no moisture remains in the detected particles after passage through the sampling system, indicating that the sampled particles were either dry on entry or contained at most a surface layer of water that evaporates easily. This is consistent with the fact that the temperatures in the vicinity of Eureka 

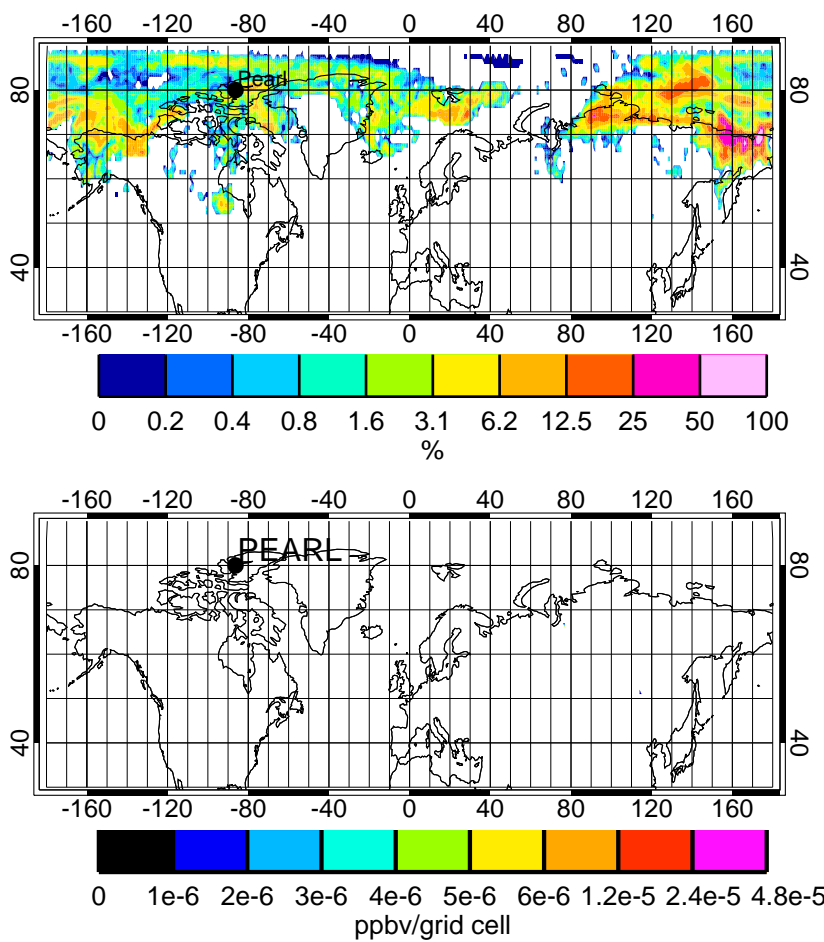

Fig. 9. The top panel shows the footprint residence time distribution for particles arriving at the receptor during the "clean" period from 20 August 2006, 00:00 UTC to 23 August 2006, 00:00 UTC. The values are expressed as a percentage of the maximum residence time $(17.7 \mathrm{~s})$ in each grid cell. The corresponding source contributions per grid cell to the mixing ratio at the receptor are shown in the bottom panel.

were about $-12{ }^{\circ} \mathrm{C}$ during the sampling period and, thus, the relative humidity of the air would have been very low after raising its temperature to $20^{\circ} \mathrm{C}$ in the inlet. Since the water was not evaporated during the high sulfate episode discussed above, therefore, we conclude that both the sulfate and water come from condensed sulfuric acid. The small amount of organic material present with the water and sulfate might be from organic aerosols coated with sulfuric acid or from separate organic particles that coincidentally have the same size distribution (Heintzenberg and Leck, 1994). The former, however, seems more likely (Nriagu et al., 1991).

All mass size distributions measured by the AMS during the two months analysed here extend from about 200 or $300 \mathrm{~nm}$ to the upper limit of the AMS at about $700 \mathrm{~nm}$. Although the lower detection limit of the AMS (given at 50\% efficiency) is at $80 \mathrm{~nm}$ (Liu et al., 2007), none of the measured size distributions show particles below about $200 \mathrm{~nm}$. The absence of ultrafine or Aitken mode particles shows there is no particle formation in the vicinity of PEARL; the arriving particles are aged and, thus, originate from distant sources. This may contrast with AMS studies in urban environments, which usually show two modes: one at 100 $200 \mathrm{~nm}$ and a larger one between 300 and $800 \mathrm{~nm}$. The
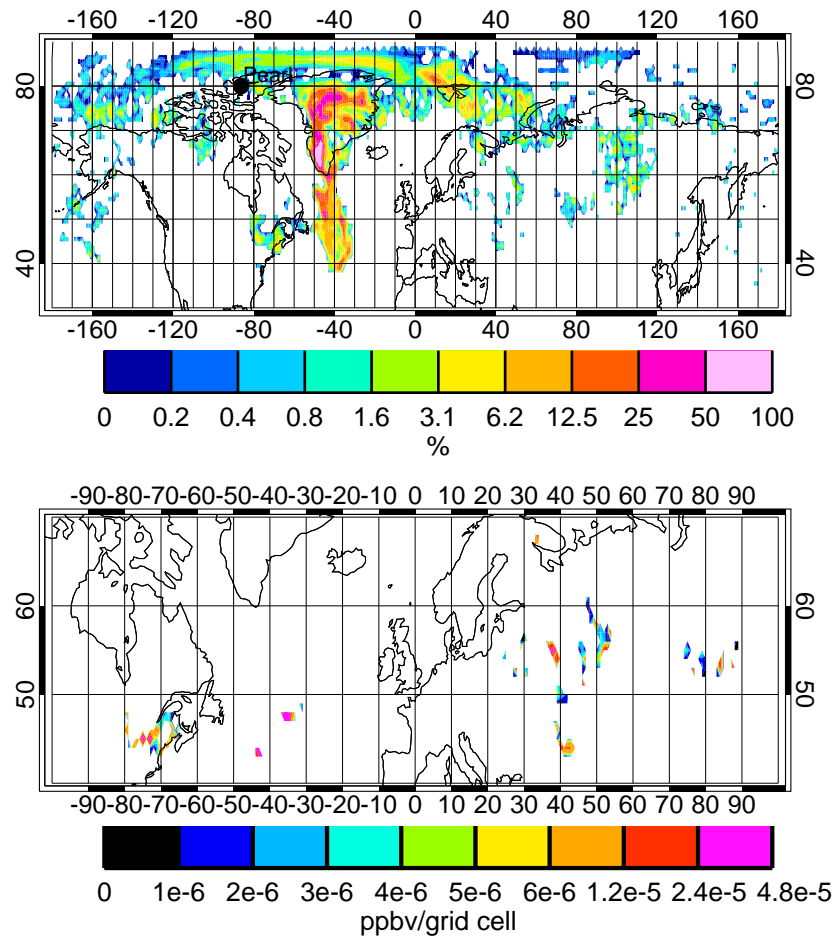

Fig. 10. Similar to Fig. 9 but for particles arriving at the receptor from 30 August 2006, 00:00 UTC to 31 August 2006, 00:00 UTC. Maximum residence time: $8.2 \mathrm{~s}$.

smaller mode is normally identified as newly-formed organic particles originating (usually) from motor vehicle emissions, whereas the larger consists of sulfate, nitrate and oxidized organics (Alfarra et al., 2004; Allan et al., 2003a; Rupakheti et al., 2005). The absence of the smaller mode at PEARL is consistent with results from rural regions, where smaller modes are usually not observed (Alfarra et al., 2004; Rupakheti et al., 2005).

\section{Lagrangian modelling}

The correlations described in the last section for some of the episodes are suggestive of common origins, so these episodes were chosen for source identification using the Lagrangian particle dispersion model FLEXPART (Stohl et al., 1998; Stohl and Thomson, 1999). FLEXPART simulates the longrange transport, diffusion, wet and dry deposition, and radioactive decay of tracers released from point, line, area or volume sources. It can be run either in the forward mode to simulate the dispersion of tracers from their sources, or backward in time to determine potential source contributions to a specified receptor. FLEXPART has been extensively validated with data from large-scale tracer experiments in North America and Europe (Stohl et al., 1998) and used in many other atmospheric transport studies. Of relevance to the present high latitude application, FLEXPART was used 

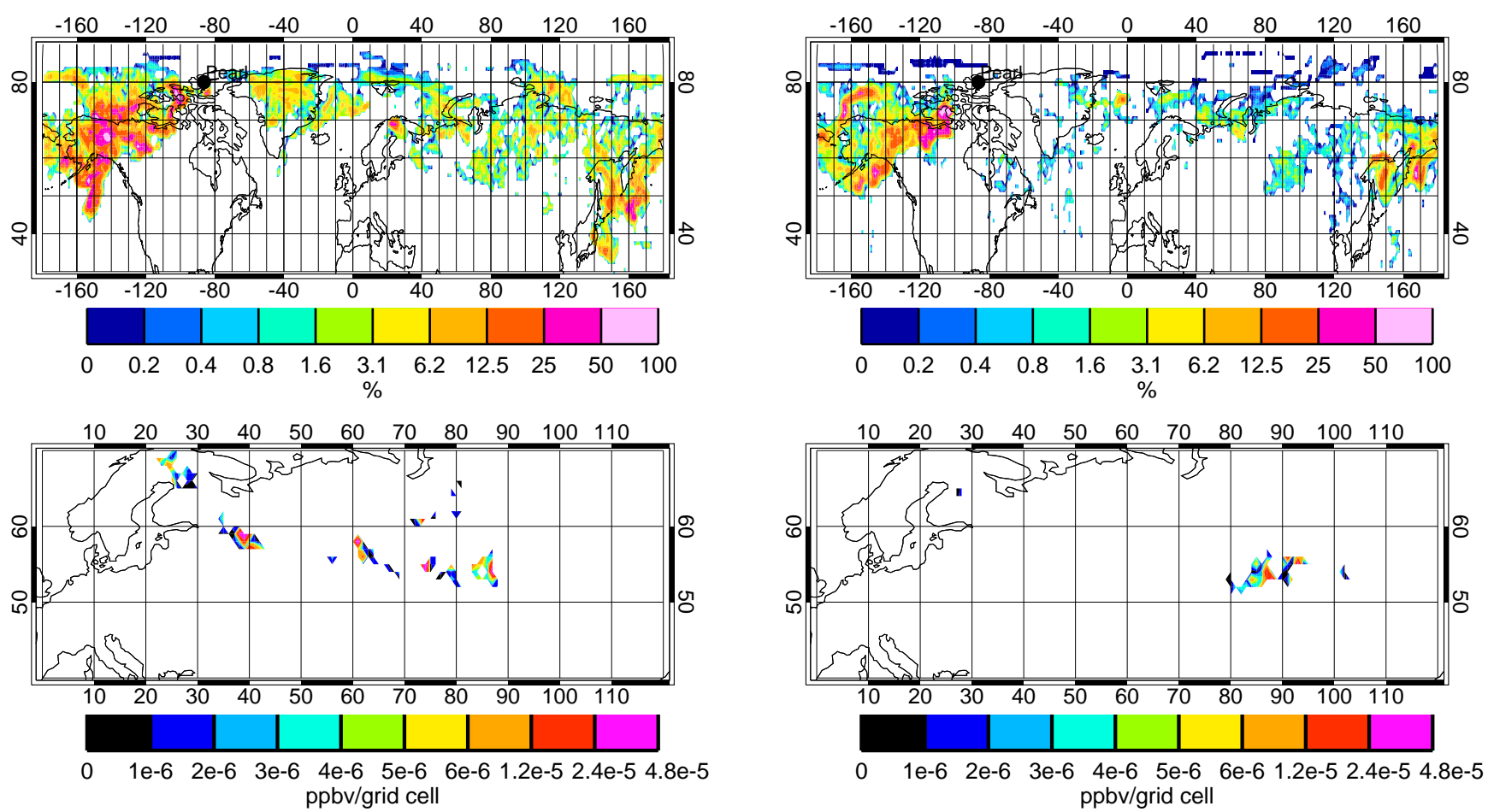

Fig. 11. Similar to Fig. 9, but for particles arriving at the receptor between 1 September 2006, 00:00 UTC and 2 September 2006, 12:00 UTC. Maximum residence time: $16.3 \mathrm{~s}$.

recently to simulate the transport of pollutant plumes from Russian (Damoah et al., 2004) and Alaskan (Damoah et al., 2006) forest fires. For the simulations reported here, FLEXPART was driven by meteorological data from the Global Forecast System (GFS) of the National Centre for Environmental Prediction using a horizontal resolution of $1^{\circ} \times 1^{\circ}$ with 26 pressure levels and a time resolution of $3 \mathrm{~h}$ (analyses at 00:00, 06:00, 12:00, 18:00 UTC; 3-hour forecasts at 03:00, 09:00, 15:00, 21:00 UTC).

We ran backward simulations using FLEXPART for the episodes noted in Fig. 2 in order to determine the origin of the air arriving at PEARL during those periods. These backward simulations are similar to that described by Seibert (2001) and Stohl et al. (2003). We released 20000 particles at the PEARL receptor location during the episode periods and simulated their transport backward in time for 20 days, forming a "retroplume". We then computed particle residence times in seconds, normalized by the total number of released particles, in the cells of a 3-D grid with $1^{\circ} \times 1^{\circ}$ horizontal resolution and a depth of $500 \mathrm{~m}$ above the surface, for each $3 \mathrm{~h}$ transport period.

The residence time in these surface grid boxes is called the source footprint (Flesch et al., 1995). It is proportional to the contribution a source of unit strength located in those grid boxes, would make to the mixing ratio at the receptor. If the absolute contributions from the grid boxes are required in

Fig. 12. Similar to Fig. 9, but for particles arriving at the receptor between 2 September 2006, 12:00 UTC and 3 September 2006, 12:00 UTC. Maximum residence time: $6.5 \mathrm{~s}$.

terms of mass concentrations for a particular species, then we multiply the residence times in the grid boxes with the source strength of that species. For the sulfate episodes discussed in the next Section, we used the $\mathrm{SO}_{2}$ emission for the year 2000 from the Emission Database for Global Atmospheric Research (EDGAR) v3.2 (Olivier et al., 2005) as a proxy for the detected sulfate, on the assumption that the $\mathrm{SO}_{2}$ would be completely oxidized during transport over the long distances to the receptor.

\section{Lagrangian results}

As discussed earlier and shown in Fig. 2, the sulfate concentrations rose significantly during the period from about 23 August to 8 September - at first gradually, then from about 30 August to 3 September, the AMS recorded sulfate concentrations more than 5 times higher than the average background. Highly variable sulfate concentrations are not unique in the AMS dataset, but the clearly demarcated nature of this example makes it particularly suitable for Lagrangian analysis. The short duration and sudden, high concentrations observed in this episode suggest that it represents the arrival of a "plume" from anthropogenic sources, so we focussed on anthropogenic sulfate emissions during this analysis.

Separate FLEXPART backward simulations were performed for the three sulfate episodes shown in Fig. 2 (episodes 1, 2a and 2b) as well as for particles arriving 
Table 1. Locations and Activities associated with the high source contributions responsible for episodes $1,2 \mathrm{a}$ and $2 \mathrm{~b}$.

\begin{tabular}{ll}
\hline Location & Population Center/Activity \\
\hline (a) Episode 1 & \\
\hline $55.7^{\circ} \mathrm{N} ; 37.6^{\circ} \mathrm{E}$ & Moscow/Heavy industry \\
$52.5^{\circ} \mathrm{N} ; 76.5^{\circ} \mathrm{E}$ & Pavlodar (Kazakstan)/Oil refining, Thermal power generation \\
$54-58^{\circ} \mathrm{N} ; 48-54^{\circ} \mathrm{E}$ & Tatarstan/Oil production \\
$53.7^{\circ} \mathrm{N}, 87.0^{\circ} \mathrm{E}$ & Novokuznetsk/Coal production \\
$46-48^{\circ} \mathrm{N}, 79-81^{\circ} \mathrm{W}$ & Timmins, Val d'Or, Sudbury (Canada)/Mining \\
$45.5^{\circ} \mathrm{N} ; 73.5^{\circ} \mathrm{W}$ & Montreal (Canada)/Oil refining \\
$40-50^{\circ} \mathrm{N} ; 30-50^{\circ} \mathrm{W}$ & Intersection of several Europe-North America shipping routes \\
$43-45^{\circ} \mathrm{N}, 40-44^{\circ} \mathrm{E}$ & Stavropol/Oil and gas production \\
\hline$(\mathrm{b}) \mathrm{Episode} \mathrm{2 \textrm {a }}$ & \\
\hline $61^{\circ} \mathrm{N}, 73^{\circ} \mathrm{E}$ & Surgut/Oil and Gas production \\
$59^{\circ} \mathrm{N}, 38^{\circ} \mathrm{E}$ & Cherepovets/Steel manufacturing \\
$56-58^{\circ} \mathrm{N}, 60-61^{\circ} \mathrm{E}$ & Yekaterinburg-Sverdlovsk/Coal, Metals refining, Thermal power generation \\
$55^{\circ} \mathrm{N}, 73.4^{\circ} \mathrm{E}$ & Omsk/Oil refining \\
$53.7^{\circ} \mathrm{N}, 87.1^{\circ} \mathrm{E}$ & Novokuznetsk/Thermal electric generation \\
\hline (c) Episode 2b & \\
\hline $56^{\circ} \mathrm{N}, 91^{\circ} \mathrm{E}$ & Achinsk/Heavy industry, Oil refining, Cement \\
$56^{\circ} \mathrm{N}, 93^{\circ} \mathrm{E}$ & Krasnoyarsk/Aluminum, Rubber \\
$54^{\circ} \mathrm{N}, 87^{\circ} \mathrm{E}$ & Novokuznetsk/Coal, Metals, Power \\
$49.7^{\circ} \mathrm{N}, 84.3^{\circ} \mathrm{E}$ & Zyryanovsk/Mining \\
\hline
\end{tabular}

during the clean period from 20 August 2006, 00:00 UTC to 23 August 2006, 00:00 UTC. Sulfate episode 1 is the relatively small one from 30 August 2006, 00:00 UTC to $31 \mathrm{Au}-$ gust 2006, 00:00 UTC. Sulfate episode 2, which starts at 1 September 2006, 00:00 UTC and ends at 3 September 2006, 00:00 UTC, has two parts - a larger one from 1 September 2006, 00:00 UTC to 2 September 2006, 12:00 UTC (episode 2a) and a smaller one from 2 September 2006, 12:00 UTC to 3 September 2006, 12:00 UTC (episode 2b).

The results from the FLEXPART simulations are shown in Figs. 9-12. The upper panels in each case show the footprint residence time distributions for particles arriving at PEARL during the respective time periods (normalized by the longest residence time). The upper panel of Fig. 9 shows the footprint for the clean air episode; that of Fig. 10 shows episode 1 and those of Figs. 11 and 12 show episodes $2 \mathrm{a}$ and $2 \mathrm{~b}$, respectively. The sequence of upper panels, beginning with Fig. 10, shows a large scale circulation pattern that moves strongly southward across eastern North America and the north Atlantic (Fig. 10), then continues eastward across northern Eurasia (Figs. 11 and 12). During this passage, it crosses regions of anthropogenic activity south of $60^{\circ} \mathrm{N}$ and picks up $\mathrm{SO}_{2}$, which is oxidized to $\mathrm{SO}_{4}^{=}$during transport to the PEARL laboratory. To identify the individual source contributions to the sulfate aerosols detected by the PEARL AMS, we multiply the footprint residence times with the $\mathrm{SO}_{2}$ emission strengths from the EDGAR inventory.
The resulting source contributions are shown in the lower panels of Figs. 9-12, respectively. For clarity, these panels show only sources with contributions equal to or greater than $10^{-6} \mathrm{ppbv/grid} \mathrm{cell.}$

For the clean air simulation (Fig. 9), the retroplume footprint is concentrated at latitudes above $60^{\circ} \mathrm{N}$, where anthropogenic activities (and $\mathrm{SO}_{2}$ emissions) are very low. Consequently, the source map in the lower panel of Fig. 9 shows correspondingly low (less than $10^{-6} \mathrm{ppbv} /$ grid cell) sulfate contributions to the mixing ratio at PEARL.

The retroplumes for episodes $1,2 \mathrm{a}$ and $2 \mathrm{~b}$, however, extend to lower latitudes, where they encounter anthropogenic $\mathrm{SO}_{2}$ sources. The upper panel of Fig. 10 shows that the longest footprint residence times for episode 1 are in Greenland, but extend southwards over the Atlantic Ocean and parts of eastern Canada down to a latitude of about $40^{\circ} \mathrm{N}$. A small part of this footprint also extends over several locations in Russia and Eastern Europe. Combining the EDGAR emission data with this footprint identifies the major source contributions to episode 1 , the locations of which are shown in the lower panel of Fig. 10. In this case, there are only a few source regions that contribute more than $10^{-6} \mathrm{ppbv} /$ grid cell scattered within the footprint and these are easily identifiable. The locations and most probable identities of the anthropogenic sources responsible for these sulfate emissions are listed in Table 1a. The sources include large cities (Montreal, Moscow), shipping routes in the Atlantic and mining, 
petroleum and coal producing regions. This shows that the Arctic atmosphere is influenced directly (within 20 days) by a variety of sources at latitudes down to at least $40^{\circ} \mathrm{N}$.

By the time episode $2 \mathrm{a}$ begins, the footprint region has moved significantly and changed its shape. This reflects both the large scale motion of the upper air and also the turbulence in the lowest meteorological layer in which the footprint is defined. Figure 11 shows that the part of the episode $2 \mathrm{a}$ footprint extending over land below $60^{\circ} \mathrm{N}$ is distributed mainly across northern Eurasia and parts of northern Japan. The source regions that contribute more than $10^{-6} \mathrm{ppbv} /$ grid cell are shown in the lower panel. Again, these are concentrated in a few easily identifiable locations of high emission, which are listed in Table 1b. These are dominated by petroleum production, metals manufacturing and thermal power plants.

The footprint has evolved further by the beginning of episode $2 b$. At this time, the part that contacts the land surface below $60^{\circ} \mathrm{N}$ is concentrated largely in eastern Eurasia and the $\mathrm{SO}_{2}$ sources contributing more than $10^{-6} \mathrm{ppbv} / \mathrm{grid}$ cell are found between $50-60^{\circ} \mathrm{N}$ and $80-100^{\circ} \mathrm{E}$ (see Fig. 12 and Table 1c). In this case, heavy industry, petroleum refining, chemical and cement processing appear to dominate the anthropogenic $\mathrm{SO}_{2}$ sources.

\section{Conclusions}

We have described the installation of an AMS at the PEARL observatory in the Canadian high Arctic and discussed several technical aspects that ensure the integrity of particles sampled from the very cold and harsh environment at the laboratory. The uniquely remote location of the laboratory at $80^{\circ} \mathrm{N}$ and an altitude of $610 \mathrm{~m}$ above sea level (in the free troposphere) make it an ideal site to study the long range transport of pollutants into the Arctic.

Since its installation, the AMS has been providing a record of the mass concentrations as well as the chemical composition and size distribution of ambient aerosol at the PEARL site. In this paper, we have reported the compositions and size distributions of the aerosols measured during selected episodes as well as during periods in which normal background was observed. We have found that some of the components have common origins, based on their high temporal correlations during certain periods.

We have also used Lagrangian modelling to examine three selected episodes during which unusually high sulfate concentrations were observed. The temporal profiles of these suggest anthropogenic origins. In all cases, these coincided with the arrival of air that had contacted the surface at latitudes below about $60^{\circ} \mathrm{N}$. Most of these lower-latitude footprints were on land, but sulfate emissions from shipping in the Atlantic were also detected. Land source regions were found in north-eastern North America and in a broad area of northern Eurasia, principally in Russia. These Lagrangian results demonstrate that there is direct transport of polluted air into the high Arctic (up to $80^{\circ} \mathrm{N}$ ) from latitudes down to $40^{\circ} \mathrm{N}$ on a time scale of $2-3$ weeks. The polluted air originates in a wide variety of industrial, resource extraction and petroleum-related activity as well as from large population centres. The quantification of this transport is important not only to our understanding of the sources of Arctic pollution, but also for international discussions aimed at its abatement. In future publications, we hope to assess the sources for other kinds of aerosols, including organics, to further elucidate the transport of these materials into the Arctic.

Acknowledgements. We are grateful for the financial assistance of CANDAC and the Canadian Foundation for Climate and Atmospheric Sciences (CFCAS) and for helpful discussions with John Jayne, Aerodyne Inc.

Edited by: R. Krejci

\section{References}

Alfarra, M. R., Coe, H., Allan, J. D., Bower, K. N., Boudries, H., Canagaratna, M. R., Jimenez, J. L., Jayne, J. T., Garforth, A. A., Li, S. M., and Worsnop, D. R.: Characterization of urban and rural organic particulate in the lower Fraser valley using two Aerodyne aerosol mass spectrometers, Atmos. Environ., 38, 57455758, 2004.

Allan, J. D., Alfarra, M. R., Bower, K. N., Williams, P. I., Gallagher, M. W., Jimenez, J. L., McDonald, A. G., Nemitz, E., Canagaratna, M. R., Jayne, J. T., Coe, H., and Worsnop, D. R.: Quantitative sampling using an Aerodyne aerosol mass spectrometer - 2. Measurements of fine particulate chemical composition in two U.K. cities, J. Geophys. Res.-Atmos., 108, 4091, doi:10.1029/2002JD002359, 2003a.

Allan, J. D., Delia, A. E., Coe, H., Bower, K. N., Alfarra, M. R., Jimenez, J. L., Middlebrook, A. M., Drewnick, F., Onasch, T. B., Canagaratna, M. R., Jayne, J. T., and Worsnop, D. R.: A generalised method for the extraction of chemically resolved mass spectra from aerodyne aerosol mass spectrometer data, J. Aerosol Sci., 35, 909-922, 2004.

Allan, J. D., Jimenez, J. L., Williams, P. I., Alfarra, M. R., Bower, K. N., Jayne, J. T., Coe, H., and Worsnop, D. R.: Quantitative sampling using an Aerodyne aerosol mass spectrometer - 1 . Techniques of data interpretation and error analysis, J. Geophys. Res.-Atmos., 108, 4090, doi:10.1029/2002JD002358, $2003 \mathrm{~b}$.

AMAP: AMAP Assessment 2002: The influence of global change on contaminant pathways to, within, and from the Arctic, 2003.

Bae, M. S., Schwab, J. J., Zhang, Q., Hogrefe, O., Demerjian, K. L., Weimer, S., Rhoads, K., Orsini, D., Venkatachari, P., and Hopke, P. K.: Interference of organic signals in highly time resolved nitrate measurements by low mass resolution aerosol mass spectrometry, J. Geophys. Res.-Atmos., 112, D22305, doi:10.1029/2007JD008614, 2007.

Bailey, R., Barrie, L. A., Halsall, C. J., Fellin, P., and Muir, D. C. G.: Atmospheric organochlorine pesticides in the western Canadian Arctic: evidence of transpacific transport, J. Geophys. Res.Atmos., 105, 11805-11811, 2000.

Barrie, L. A., Staebler, R., Toom, D., Georgi, B., Denhartog, G., Landsberger, S., and Wu, D.: Arctic aerosol size-segregated 
chemical observations in relation to ozone depletion during polar sunrise experiment 1992, J. Geophys. Res.-Atmos., 99, 2543925451, 1994.

Bergin, M. H., Ogren, J. A., Schwartz, S. E., and McInnes, L. M.: Evaporation of ammonium nitrate aerosol in a heated nephelometer: implications for field measurements, Environ. Sci. Technol., 31, 2878-2883, 1997.

Canagaratna, M. R., Jayne, J. T., Jimenez, J. L., Allan, J. D., Alfarra, M. R., Zhang, Q., Onasch, T. B., Drewnick, F., Coe, H., Middlebrook, A., Delia, A., Williams, L. R., Trimborn, A. M., Northway, M. J., DeCarlo, P. F., Kolb, C. E., Davidovits, P., and Worsnop, D. R.: Chemical and microphysical characterization of ambient aerosols with the aerodyne aerosol mass spectrometer, Mass Spectrom. Rev., 26, 185-222, 2007.

Covert, D. S. and Heintzenberg, J.: Size distributions and chemicalproperties of aerosol at Ny Ålesund, Svalbard, Atmos. Environ. Part A-General Topics, 27, 2989-2997, 1993.

Damoah, R., Spichtinger, N., Forster, C., James, P., Mattis, I., Wandinger, U., Beirle, S., Wagner, T., and Stohl, A.: Around the world in 17 days - hemispheric-scale transport of forest fire smoke from Russia in May 2003, Atmos. Chem. Phys., 4, 13111321, doi:10.5194/acp-4-1311-2004, 2004.

Damoah, R., Spichtinger, N., Servranckx, R., Fromm, M., Eloranta, E. W., Razenkov, I. A., James, P., Shulski, M., Forster, C., and Stohl, A.: A case study of pyro-convection using transport model and remote sensing data, Atmos. Chem. Phys., 6, 173185, doi:10.5194/acp-6-173-2006, 2006.

Flesch, T. K., Wilson, J. D., and Yee, E.: Backward-time lagrangian stochastic dispersion models and their application to estimate gaseous emissions, J. Appl. Meteorol., 34, 1320-1332, 1995.

Fry, J. L., Kiendler-Scharr, A., Rollins, A. W., Wooldridge, P. J., Brown, S. S., Fuchs, H., Dubé, W., Mensah, A., dal Maso, M., Tillmann, R., Dorn, H.-P., Brauers, T., and Cohen, R. C.: Organic nitrate and secondary organic aerosol yield from $\mathrm{NO}_{3}$ oxidation of $\beta$-pinene evaluated using a gas-phase kinetics/aerosol partitioning model, Atmos. Chem. Phys., 9, 14311449, doi:10.5194/acp-9-1431-2009, 2009.

Gormley, P. G. and Kennedy, M.: Diffusion from a stream flowing through a cylindrical tube, Proceedings of the Royal Irish Academy, A52, 163-169, 1949.

Halsall, C. J., Bailey, R., Stern, G. A., Barrie, L. A., Fellin, P., Muir, D. C. G., Rosenberg, B., Rovinsky, F. Y., Kononov, E. Y., and Pastukhov, B.: Multi-year observations of organohalogen pesticides in the Arctic atmosphere, Environ. Pollut., 102, 51-62, 1998.

Halsall, C. J., Barrie, L. A., Fellin, P., Muir, D. C. G., Billeck, B. N., Lockhart, L., Rovinsky, F. Y., Kononov, E. Y., and Pastukhov, B.: Spatial and temporal variation of polycyclic aromatic hydrocarbons in the Arctic atmosphere, Environ. Sci. Technol., 31, 3593 3599, 1997.

Heidam, N. Z., Wahlin, P., and Kemp, K.: Arctic aerosols in Greenland, Atmos. Environ. Part A-General Topics, 27, 3029-3036, 1993.

Heintzenberg, J.: Arctic haze - air-pollution in polar-regions, Ambio, 18, 50-55, 1989.

Heintzenberg, J. and Leck, C.: seasonal-variation of the atmospheric aerosol near the top of the marine boundary-layer over Spitsbergen related to the Arctic sulfur cycle, Tellus B, 46, 5267, 1994.
Hillamo, R., Kerminen, V. M., Aurela, M., Makela, T., Maenhaut, W., and Leck, C.: Modal structure of chemical mass size distribution in the high Arctic aerosol, J. Geophys. Res.-Atmos., 106, 27555-27571, 2001.

Hinds, W. C.: Aerosol Technology: Properties, Behavior, and Measurement of Airborne Particles, John Wiley \& Sons, New York, 1999.

Hoff, R. M., Leaitch, W. R., Fellin, P., and Barrie, L. A.: Mass size distributions of chemical-constituents of the winter Arctic aerosol, J. Geophys. Res.-Oceans Atmos., 88, 947-956, 1983.

Hung, H., Blanchard, P., Halsall, C. J., Bidleman, T. F., Stern, G. A., Fellin, P., Muir, D. C. G., Barrie, L. A., Jantunen, L. M., Helm, P. A., Ma, J., and Konoplev, A.: Temporal and spatial variabilities of atmospheric polychlorinated biphenyls (PCBs), organochlorine (OC) pesticides and polycyclic aromatic hydrocarbons (PAHs) in the Canadian Arctic: results from a decade of monitoring, Sci. Total Environ., 342, 119-144, 2005.

Incropera, F. P. and DeWitt, D. P.: Fundamentals of Heat and Mass Transfer, Wiley, New York, 1999.

Jayne, J. T., Leard, D. C., Zhang, X. F., Davidovits, P., Smith, K. A., Kolb, C. E., and Worsnop, D. R.: Development of an aerosol mass spectrometer for size and composition analysis of submicron particles, Aerosol Sci. Technol., 33, 49-70, 2000.

Jimenez, J. L., Jayne, J. T., Shi, Q., Kolb, C. E., Worsnop, D. R., Yourshaw, I., Seinfeld, J. H., Flagan, R. C., Zhang, X. F., Smith, K. A., Morris, J. W., and Davidovits, P.: Ambient aerosol sampling using the Aerodyne Aerosol Mass Spectrometer, J. Geophys. Res.-Atmos., 108, 8425, doi:10.1029/2001JD001213, 2003.

Lammel, G., Sehili, A. M., Bond, T. C., Feichter, J., and Grassl, H.: Gas/particle partitioning and global distribution of polycyclic aromatic hydrocarbons - a modelling approach, Chemosphere, 76, 98-106, 2009.

Liu, P. S. K., Deng, R., Smith, K. A., Williams, L. R., Jayne, J. T., Canagaratna, M. R., Moore, K., Onasch, T. B., Worsnop, D. R., and Deshler, T.: Transmission efficiency of an aerodynamic focusing lens system: comparison of model calculations and laboratory measurements for the aerodyne aerosol mass spectrometer, Aerosol Sci. Technol., 41, 721-733, 2007.

Narukawa, M., Kawamura, K., Li, S. M., and Bottenheim, J. W.: Dicarboxylic acids in the Arctic aerosols and snowpacks collected during Alert 2000, Atmos. Environ., 36, 2491-2499, 2002.

Nriagu, J. O., Coker, R. D., and Barrie, L. A.: Origin of sulfur in Canadian Arctic haze from isotope measurements, Nature, 349, 142-145, 1991.

Nyeki, S., Coulson, G., Colbeck, I., Eleftheriadis, K., Baltensperger, U., and Beine, H. J.: Overview of aerosol microphysics at Arctic sunrise: measurements during the NICE renoxification study, Tellus B, 57, 40-50, 2005.

Oehme, M.: Further evidence for long-range air transport of polychlorinated aromates and pesticides - North-America and Eurasia to the Arctic, Ambio, 20, 293-297, 1991.

Oehme, M. and Ottar, B.: The long-range transport of polychlorinated hydrocarbons to the Arctic, Geophys. Res. Lett., 11, 11331136, 1984.

Olivier, J. G. J., Van Ardenne, J. A., Dentner, F., Ganzeveld, L., and Peters, J. A. H.: Recent trends in global greenhouse gas emissions regional trends and spatial distribution of key sources, in: Non- $\mathrm{CO}_{2}$ Greenhouse Gases (NCGG4), A. van Amstel (coord.), 
Millpress, Rotterdam, 325-330, 2005.

Pacyna, J. M.: The origin of Arctic air-pollutants - lessons learned and future-research, Sci. Total Environ., 161, 39-53, 1995.

Polissar, A. V., Hopke, P. K., and Harris, J. M.: Source regions for atmospheric aerosol measured at Barrow, Alaska, Environ. Sci. Technol., 35, 4214-4226, 2001.

Ricard, V., Jaffrezo, J. L., Kerminen, V. M., Hillamo, R. E., Teinilä, K., and Maenhaut, W.: Size distributions and modal parameters of aerosol constituents in northern Finland during the European Arctic Aerosol study, J. Geophys. Res.-Atmos., 107, 4208, doi:10.1029/2001JD001130, 2002.

Rupakheti, M., Leaitch, W. R., Lohmann, U., Hayden, K., Brickell, P., Lu, G., Li, S. M., Toom-Sauntry, D., Bottenheim, J. W., Brook, J. R., Vet, R., Jayne, J. T., and Worsnop, D. R.: An intensive study of the size and composition of submicron atmospheric aerosols at a rural site in Ontario, Canada, Aerosol Sci. Technol., 39, 722-736, 2005.

Saarikoski, S., Timonen, H., Saarnio, K., Aurela, M., Järvi, L., Keronen, P., Kerminen, V.-M., and Hillamo, R.: Sources of organic carbon in fine particulate matter in northern European urban air, Atmos. Chem. Phys., 8, 6281-6295, doi:10.5194/acp-86281-2008, 2008.

Sehili, A. M. and Lammel, G.: Global fate and distribution of polycyclic aromatic hydrocarbons emitted from Europe and Russia, Atmos. Environ., 41, 8301-8315, 2007.

Seibert, P.: Inverse modelling with a Lagrangian particle dispersion model, application to point releases over limited time intervals, in: Air pollution Modeling and its Application XIV, Proceedings of ITM Boulder, edited by: Gryning, S. E. and Schiermeier, F. A., Plenum, New York, 381-389, 2001.

Sirois, A. and Barrie, L. A.: Arctic lower tropospheric aerosol trends and composition at Alert, Canada: 1980-1995, J. Geophys. Res.-Atmos., 104, 11599-11618, 1999.

Staebler, R., Toom-Sauntry, D., Barrie, L., Langendorfer, U., Lehrer, E., Li, S. M., and Dryfhout-Clark, H.: Physical and chemical characteristics of aerosols at Spitsbergen in the spring of 1996, J. Geophys. Res.-Atmos., 104, 5515-5529, 1999.
Stelson, A. W. and Seinfeld, J. H.: Relative humidity and temperature dependence of the ammonium nitrate dissociation constant, Atmos. Environ., 41, 126-135, 2007.

Stohl, A., Forster, C., Eckhardt, S., Spichtinger, N., Huntrieser, H., Heland, J., Schlager, H., Wilhelm, S., Arnold, F., and Cooper, O.: A backward modeling study of intercontinental pollution transport using aircraft measurements, J. Geophys. Res.-Atmos., 108, 4370, doi:10.1029/2002JD002862, 2003.

Stohl, A., Hittenberger, M., and Wotawa, G.: Validation of the lagrangian particle dispersion model FLEXPART against largescale tracer experiment data, Atmos. Environ., 32, 4245-4264, 1998.

Stohl, A. and Thomson, D. J.: A density correction for lagrangian particle dispersion models, Bound.-Lay. Meteorol., 90, 155-167, 1999.

Ström, J., Umegard, J., Torseth, K., Tunved, P., Hansson, H. C., Holmen, K., Wismann, V., Herber, A., and Konig-Langlo, G.: One year of particle size distribution and aerosol chemical composition measurements at the Zeppelin station, Svalbard, March 2000-March 2001, Phys. Chem. Earth, 28, 1181-1190, 2003.

Teinilä, K., Hillamo, R., Kerminen, V. M., and Beine, H. J.: Aerosol chemistry during the NICE dark and light campaigns, Atmos. Environ., 37, 563-575, 2003.

Teinilä, K., Hillamo, R., Kerminen, V. M., and Beine, H. J.: Chemistry and modal parameters of major ionic aerosol components during the NICE campaigns at two altitudes, Atmos. Environ., 38, 1481-1490, 2004.

Xie, Y. L., Hopke, P. K., Paatero, P., Barrie, L. A., and Li, S. M.: Locations and preferred pathways of possible sources of Arctic aerosol, Atmos. Environ., 33, 2229-2239, 1999.

Zhang, Q., Canagaratna, M. R., Jayne, J. T., Worsnop, D. R., and Jimenez, J. L.: Time- and size-resolved chemical composition of submicron particles in Pittsburgh: implications for aerosol sources and processes, J. Geophys. Res.-Atmos., 110, D07S09, doi:10.1029/2004JD004649, 2005. 